\title{
Information behavior of the academic community of FMVZ-UNAM
}

Nora Lucía Galván Ochoa (https://orcid.org/0000-0003-2760-2688)(1)* José Ricardo Manriquez Betanzos (https://orcid.org/0000-0003-0771-6258)(2)

(1) Universidad Nacional Autónoma de México. Facultad de Medicina Veterinaria y Zootecnia. Departamento de Publicaciones.

(2) Comisión Nacional de Derechos Humanos. México

* corresponding author. E-mail: galvan@unam.mx

\section{Abstract}

During 2010, at the Facultad de Medicina Veterinaria y Zootecnia of the Universidad Nacional Autónoma de México (FMVZ-UNAM) we analyzed the influence of metadata over its website according to the search engines used by the academic community. This document serves only the second specific objective of the research: to know the academic profile, the informative behavior and the veterinary information needs of the academic community of the FMVZ-UNAM. The methodological tool was the design and implementation of an online survey. We received 215 responses, two thirds answered academic staff, the rest, undergraduate and postgraduate students. In relation to information behavior, an Internet-usage index was developed, with which it was determined that $64 \%$ of this community uses four or five information services on the Internet, This means that the network is widely used to seek information and as communication media. This community search for more veterinary information related to dogs, dairy cattle and sheep, compared to other animal species; while animal welfare, zoonosis and molecular biology are the topics of greatest interest.

Keywords: information behavior; veterinary information needs; online survey 


\section{Introduction}

Advances in Information and Communication Technologies (ICT) and mass access to the Internet have promoted the development of new tools and applications that influence the way information is generated, exchanged and stored. In the face of the huge increase in content on the Internet, of multiple origins, two actors have emerged in parallel: searchengines and users.

The purpose of search-engines is to find the most effective method for extracting relevant data from large volumes of information. The user-searches are a dynamic and interactive process that starts from an initial exploration through intuitive interfaces. It is important to remember that information is not a primary need -as it is food, water, shelter, among other-. While the person knows well what is essential for his survival, in the case of information, the user does not necessarily know what he wants; moreover, it is intangible, visceral, unknown and even unspecific. ${ }^{(1)}$

From the perspective of the information behavior of individuals, that is, the set of facts that manifest themselves in the search and retrieval of information on the Internet, it has been found that $80 \%$ of searches on the Internet are made through search-engines; it is also estimated that $95 \%$ of internet traffic is due to the use of these search tools. When users view results pages, most only check the first ten results. Only $1 \%$ reach the third page. ${ }^{(2)}$

Users' information needs and information behavior change over time and are strongly influenced by their academic preparation. In its evolutionary process, humanity has always moved in search of satisfying its needs to adapt to the surrounding environment. Today, access to information in a timely, suitable, relevant and accurate manner impacts on the development of society; satisfying its need for information allows it to have the elements to approach knowledge, which allows a better interaction with the environment and its society compared to a situation of ignorance. ${ }^{(3)}$ 
In Mexico, the work of educational organizations strengthens national identity; on the basis of the first article of the Ley Orgánica de la Universidad Nacional de México, these organizations make fundamental contributions on national conditions and problems, and spread the benefits of culture. ${ }^{(4)}$ This is why these types of organizations are committed to adapting themselves in an analytical and coherent manner to the new processes of information generation, transfer and use..$^{(5)}$

A key factor for community development is access to information, hence the imperative to manage it, whose fundamental objective is to know the information that is held and follow up with the resources that will impact the development of those communities. $^{(6)}$

In 2010 in the FMVZ-UNAM we conducted a research on the influence of metadata on the visibility of its websites. Here, we show the fulfillment of the second specific objective, in which we investigate the profile of the academic community, its informative behavior and its information needs on the internet, by analyzing the results of the application of the online survey designed specifically for research (Annex 1$)^{1}$. The academic community of the FMVZ-UNAM is made up of undergraduate and postgraduate students and academic staff, that carries out teaching and research activities or specific and systematic tasks of the academic programs.

\section{Material and methods}

For the process of designing and adapting the survey, we advised staff of the Educational Guidance and Mentoring Department; for the programming, implementation on a server and collecting the responses of the online survey, the Computer department participated; for the terminological analysis of the answers, we advised with a specialist in scientific writing of the Veterinaria México journal

\footnotetext{
${ }^{1}$ The text of the survey is presented in its original language.
} 
Online survey

Procedure for the online survey

1. Designing the information scheme to know the profile of the academic community of the FMVZ-UNAM that search for veterinary information on the internet. It was determined that it was necessary to know the academic level, his main activity within the faculty, the animal species of his interest and his specialty in veterinary medicine and zootechnics. In relation to its informative behavior: what are the main uses of the Internet?, what search-engines are used to locate veterinary information? How does the user set out their search strategies? and what does the user do with the results that the search tool delivers?

2. Exploratory study. First, we submitted the battery of questions to the scrutiny of some members of the academic community, asking them to tell us if the questions were intelligible and if the objective of knowing the profile and the informative behavior of the community was covered. Then, with the advice of the Department of Educational Guidance and Mentoring of the FMVZ-UNAM specialized in survey development, the questions were adjusted.

3. Implementation of the online survey. The FMVZ-UNAM network infrastructure was used to launch the online survey, which would optimize time and resources, achieve greater outreach and immediate response; as well as, reduce errors in the capture of answers and maintain the confidentiality of information. In this process the resources were identified, for this, it was considered that the trend for the development of applications in institutions of higher education is the use of open source. The technological resources were the Apache version 2 web server, the PHP version 4 programming language and a database with the relational database management system Mysql version 5. 
Based on the information scheme and considering the survey questions, a database was designed consisting of a series of tables, each corresponding to a survey question; this is because most of them have multiple answers.

Subsequently, the operation was tested locally. That is, it was checked on a personal computer to check the consistency and integrity of the responses that were stored in the local database. Once the tests were completed, the application was hosted on the FMVZ-UNAM intranet, that is, it was installed in a directory of the Faculty's server, the database was created on the server and the permissions were assigned to store the answers.

Then it was also checked that the application was working on the server, for this the access was confirmed and the integrity of the database was eventually released the application. Annex 1 shows the full text of the online survey in its original language.

\section{Survey users}

In order to encourage the FMVZ-UNAM academic community to respond to the online survey, support was sought from the Academic Secretariat, the Professional Studies Division and the Graduate Studies Division, bodies that provided updated e-mail lists of academic staff, undergraduate and postgraduate students. By e-mail, the academic community was invited to reply to the survey, were told that the aim was to learn about the search strategies used by the academic community of the Faculty to retrieve veterinary information via the internet and, that the result would be used in a research on visibility of the FMVZ-UNAM websites.

In the collection of responses, each of the tables in the response database was taken and exported to spreadsheets to be integrated into a single table.

\section{Enquery}

To know the information needs, we standardize the search strategies of question seven (“7.- Escriba uno o varios ejemplos que usted emplea para realizar sus búsquedas de 
información en internet", see Annex 1). The question was configured so that users could respond with the words they usually use to search for veterinary information on the internet.

Given the diversity of forms that people proposes their search strategy, we begin with an orthographic revision in Spanish, for which we rely on the Dictionary of the Spanish Language (DRAE) and, for those raised in English, verified its correct writing with the Google translator (http://translate.google.com).

In order to suppress meaningless words of veterinary information (pronouns, articles, conjunctions, etc.) the grammatical nexus were removed. In strategies that contained references to an animal species, the name was left as a noun and in singular. It was joined with dash the words that constitute nominal phrase, for example, "cuerpolúteo", "fauna-silvestre", "tortuga-marina", "rural-development", "medicina-interna", "plantamedicinal'. This was done because if each word of the nominal phrase were to be isolated, it would not give the expected meaning to the terminology of veterinary medicine and zootechnics; so, as suggested, the grammatical units of the whole acquire the required meaning.

On the other hand, the derivations (from plurals, adjectives, verbs) were converted to noun, for example: "parasitaria" and "parasitología", they remained as "parásito"; "virología", such "virus", "équido", such "equine", "ganado-bovino", such "bovino", "ganadoovino" such "ovino". This standardization allowed word groups to have more frequency, rather than many infrequent word groups. At this stage, the thesaurus of the National Agricultural Library of the United States Department of Agriculture was used to standardize words. ${ }^{(7)}$

Categorizing the strategies

In accordance with the current Veterinary Medicine and Zootechnics curricula of the FMVZ-UNAM ${ }^{(8)}$ and the academic training related to this area of knowledge of the 
author, search strategies were categorized in the five generic work objects of the profession (Table 1), with the aim of obtaining fewer groups of strategies that could be more frequently.

Table 1. Generic working objects of veterinary medicine and zootechnics

\section{Results}

\begin{tabular}{|l|}
\hline Animal medicine and health \\
\hline Livestock production and economy \\
\hline Food quality and safety \\
\hline Public health \\
\hline Environmental protection and ecosystem care \\
\hline
\end{tabular}

215 surveys and 351 standardized search strategies were obtained.

\section{Profile}

Sixty-three per cent of the respondents were academic staff of FMVZ-UNAM (Table 2), and the majority of them were post-graduate (Table 3).

Table 2. Question 1: Main academic activity in the Faculty

\begin{tabular}{|l|r|l|}
\hline Total number of students & 78 & $36 \%$ \\
\hline Total Academics & 135 & $63 \%$ \\
\hline People who did not answer academic level or activity & 2 & $1 \%$ \\
\hline
\end{tabular}

Table 3. Question 2: Academic level

\begin{tabular}{|l|r|}
\hline Total number of surveys & 215 \\
\hline No level or activity answered & 2 \\
\hline Academics who did not indicate their level & 3 \\
\hline Number of undergraduate students & 43 \\
\hline Postgraduate students & 35 \\
\hline Academics with bachelor's degrees & 23 \\
\hline Academics with bachelor's degrees & 109 \\
\hline
\end{tabular}

\section{Information needs}

According to the survey, there is a greater proportion of members of the FMVZ-UNAM academic community who are interested in or specialize in dogs, dairy cattle and sheep. The topics of greatest interest are animal welfare, zoonosis and molecular biology, while 
those of least interest include equine gastroenterology, ornate-fish medicine and fish production.

From the 215 surveys, 351 search strategies were obtained and categorized by generic working objects of veterinary medicine and zootechnics. Table 4 shows the frequencies at which we classify search strategies, giving an idea that the most needed topic for information is animal health and medicine.

Table 4. Frequencies of the categorized strategies according to the generic objects of Veterinary medicine and zootechnics

\begin{tabular}{|c|l|c|}
\hline Category & Working objects of veterinary medicine and zootechnics & Frequency \\
\hline A & Animal medicine and health & 156 \\
\hline B & Livestock production and economy & 113 \\
\hline C & Food quality and safety & 10 \\
\hline D & Public health & 26 \\
\hline E & Environmental protection and ecosystem care & 46 \\
\hline
\end{tabular}

\section{Information behavior}

For the diagnosis of the informative behavior of the academic community of the FMVZ-UAM in the search for veterinary information on the internet, we asked "3. You use the internet to". Seven options were offered; one or several of them could be selected:

1. Check your email account

2. Review the bibliography

3. Consultation of bibliographic databases

4. Visit sites of interest

5. Download programs and updates for my PC

6. I never use it

7. Other use of

Internet-use index by the FMVZ-UNAM community

In this research project, an Internet-use index was created to provide an overview of how much the academic community used the Internet. To this end, the options offered in question 3 of the survey are given the same importance and value $=1$. Subsequently, values were added in each survey and with the additions in the options of this question 
four categories were created for the index of use given to the internet: much, medium, little and not specified.

It was found that $64 \%$ of the users who responded to the survey used the Internet extensively as they selected from four to five uses. $29 \%$ make average use of the Internet (selected two or three of the options), $6 \%$ use a little the Internet (selected one option), and only three surveys (1\%) did not specify whether or not to use the Internet. In no case was selected the option "I never use it".

On the other hand, Google is the most used search engine, and the search-engine is decisive for the user to enter a page. According to the answers to question 8,140 of them selected the first option (the short description is appropriate to what you are searching for). The FMVZ-UNAM community has become accustomed to the use of these search tools, because it attends the data of the results page that the search-engine gives it, 114 users responded that they enter a page because they identified it as academic site.

In question 9 "From the results presented to you, the information most useful is because", 139 answers were for "I can get the full text". That is, an electronic page is useful for the user when it offers the facility to obtain the complete information of what is published, either because the resource is open access or because the computers from which the users connects to an editorial site, or because it belongs to a network with free access.

From question 10 "From the information presented to you by the search-engine, the one that DOES NOT COVER YOUR OBJECTIVE is because of"; 134 answered "They charge for having access to the full text". From question 11, "about On average, how many results appear in your search engine you enter?", it appears that the academic community of the FMVZ-UNAM reviews quite a few sites because of the search results pages $36 \%$ visit more than ten results, and $31 \%$, between five and ten. Finally, most of this academic community tracks text and images. 


\section{Discussion}

Educational organizations serve as providers of information and, in some way, organize their academic production, so they become research subjects in information management, as Kurtz ${ }^{(9)}$ shows in his analysis of institutional repositories. These organizations generally have the task of disseminating their academic information, thus taking responsibility for processing, representing and storing it to ensure its availability and facilitate its access when needed, with which they fulfil their mission by contributing to social communication; ${ }^{(10)}$ in this regard, we consider that the FMVZ-UNAM, as an educational organization, should promote research on information management to influence dissemination policies, which would benefit its community by publicizing its academic output, as to whether the educational organization provides information to society; and as indicated in its accreditation page ${ }^{(11)}$ in the constant evaluation process to which it is committed, it would continue to adhere to international quality standards.

Although requiring information is a secondary necessity, it is recommended that it would be contextualized on the basis of its meaning and scope in order to adapt the recovery systems to the interconnection of knowledge generated in educational organizations with the search for information. ${ }^{(1)}$

According to Calva González ${ }^{(3)}$, the online survey is a resource to capture information and to be able to describe the profile, information needs and information behavior of a community; on the other hand, as stated by Hellriegel et al. ${ }^{(12)}$, surveys are a method of exploring the environment to value an organization's interests.

\section{Conclussions}

During the analysis of the academic profile, information behavior and veterinary information needs of this academic community, an indicator was created to estimate the internet-use index, which represented an opportunity to explore alternatives to evaluate the use of the Internet as a media of information search and communication. 
It is considered that the academic community of FMVZ-UNAM is accustomed to different communication resources available on the Internet, as a good number and quality of responses were obtained when they were invited to reply to the online survey via e-mail.

From this work, the profile of the FMVZ-UNAM community, its needs for veterinary information with specific interests and, in general, its informative behavior were better known. This enriched our professional experience, because it analyzed a reality in the face of the organizational policies to which most research in educational organizations is subjected. 
Aknowledgements

This research was carried out with the multidisciplinary work of the veterinary doctor NLGO, computer engineer RB and the consultancy in terminology and survey development of Glandy Horita and Angela Cárdenas. In addition, we have the organizational support of FMVZ-UNAM, which generously shared the use of the computer infrastructure and the collaboration of the Secretariat of Continuing Education and Technology, the General Secretariat, and the Division of Professional Studies, who helped with the logistics to involve the academic community in the online survey. 


\section{References}

1. Cole C. A theory of information need for information retrieval that connects information to knowledge. J Am Soc Inf Sci Technol. 2011;62(7):1216-31.

2. Zhang J, Dimitroff $A$. The impact of webpage content characteristics on webpage visibility in search engine results (part I). Inf Process Manag. 2005;41(3):665-90.

3. Calva-González JJ. Satisfacción de usuarios: la investigación sobre las necesidades de información. CdMx: UNAM, Centro Universitario de Investigaciones Bibliotecológicas; 2009.

4. Ley Orgánica de la Universidad Nacional Autónoma de México. p. 18.

5. Galván-Ochoa NL. Análisis y demostración de la influencia de los metadatos en la visibilidad de los sitios web de la Facultad de Medicina Veterinaria y Zootecnia de la UNAM [máster]. La Habana, Cuba: Universidad de la Habana-Cátedra UNESCOUniversidad Autónoma Metropolitana; 2011.

6. Tirador Ramos J. El Dominio y su implicación para la gestión de la información. Investig Bibl [internet]. abril de 2010 [citado el 14 de enero de 2020];24(50):49-60. Disponible en: http://www.scielo.org.mx/scielo.php?script=sci_abstract\&pid=S0187$358 \times 2010000100004 \& \operatorname{lng}=e s \& n r m=i s o \& t \operatorname{lng}=e s$

7. Instituto Interamericano de Cooperación para la Agricultura (IICA), Biblioteca Nacional de Agricultura de los EE.UU. Tesauro agrícola y glosario [internet]. [citado el 17 de enero de 2020]. Disponible en: https://agclass.nal.usda.gov/agt_es.shtml

8. H. Consejo Técnico de la FMVZ. Plan de estudios de la Licenciatura en Medicina Veterinaria y Zootecnia (1155) [internet]. Universidad Nacional Autónoma de México; 2005. Disponible en: http://www.fmvz.unam.mx/fmvz/p_estudios/Plan_Estudios_2006.pdf

9. Kurtz M. Dublin Core, DSpace, and a brief analysis of three university repositories. Inf Technol Libr. marzo de 2010;29(1):40-6.

10. Matos-Pérez EN. De la descripción bibliográfica a la asignación de metadatos: un llamado al orden. ACIMED [internet]. 2006 [citado el 15 de enero de 2020];14(6):0-0.

Disponible en: http://scielo.sld.cu/scielo.php?script=sci_abstract\&pid=S1024-

94352006000600012\&lng=es\&nrm=iso\&tlng=es

11. Facultad de Medicina Veterinaria y Zootecnia // UNAM [internet]. Acreditación FMVZ-UNAM. [citado el 15 de enero de 2020]. Disponible en:

http://www.fmvz.unam.mx/fmvz/principal/acreditacion.html

12. Hellriegel D, Jackson SE, Slocum JW, Velazquez JA. Administración: un enfoque basado en competencias. 10a ed. DF, México: Thomson; 2005. 540 p. 
Annex 1. Complete text of the online survey

El objetivo de esta encuesta es conocer las estrategias de búsqueda que utiliza la comunidad académica de la FMVZ-UNAM en la recuperación de información veterinaria en internet. El resultado se empleará en una investigación sobre visibilidad de los sitios Web de nuestra Facultad lo que redundará en mejorar la calidad de servicios de internet para su comunidad académica.

IMPORTANTE: La encuesta es anónima.

1.- Seleccione cuál es el nivel académico que actualmente tiene o cursa

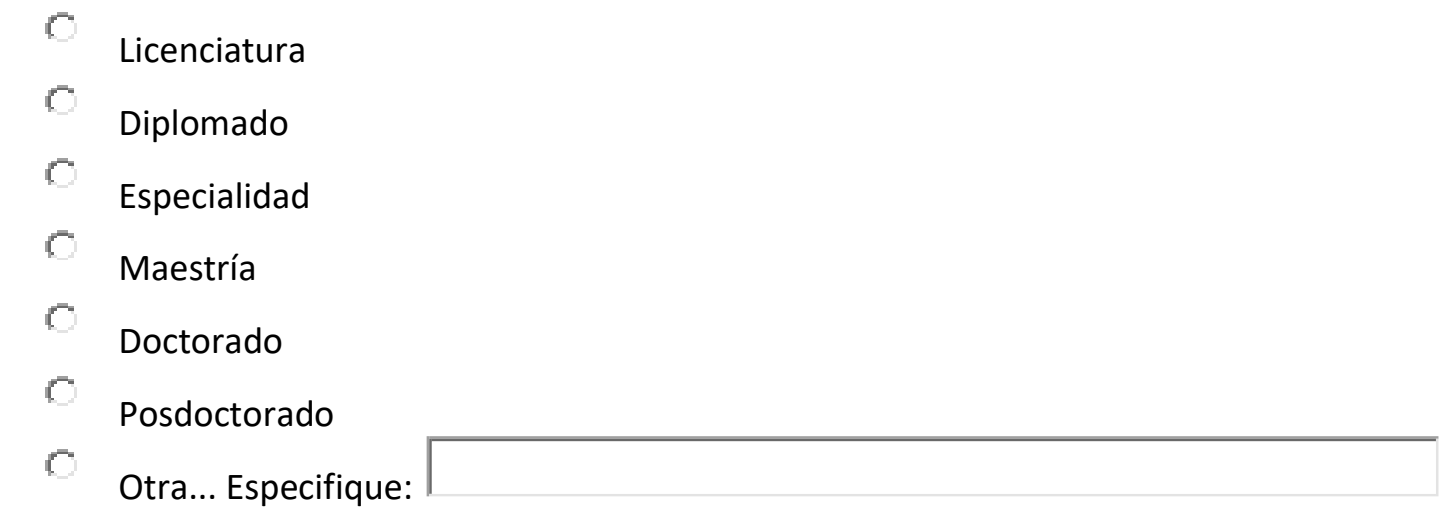

2.-¿Cuál es su principal actividad académica en la Facultad?

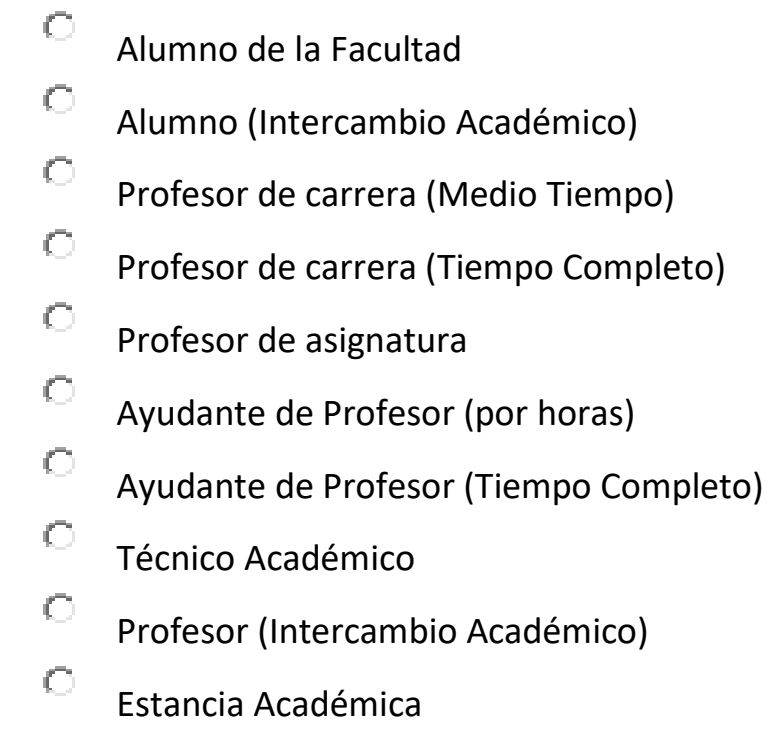


3.-Usted utiliza internet, para

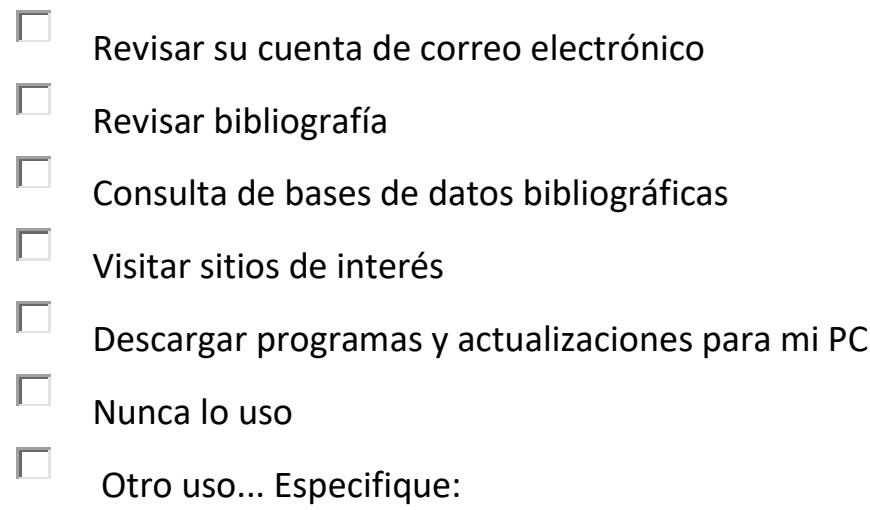

4.-¿¿Qué especies animales son las de su interés o en cuáles es Usted especialista?

\begin{tabular}{|c|c|c|}
\hline Abejas & $\Gamma$ & Gatos \\
\hline Aves de compañía & $\Gamma$ & Mascotas no tradicionales (hurón, iguanas, etc) \\
\hline Aves de producción & $\Gamma$ & Ovinos \\
\hline Bovinos de carne & Г & Peces de consumo \\
\hline Bovinos de leche & Г & Peces de ornato \\
\hline Caprinos & Г & Perros \\
\hline Conejos & Г & Porcinos \\
\hline Equinos & Г & Venados \\
\hline Fauna silvestre & Г & Otra... Especifique: \\
\hline
\end{tabular}

5.-¿Qué temas son los de su interés en su búsqueda de información en internet?

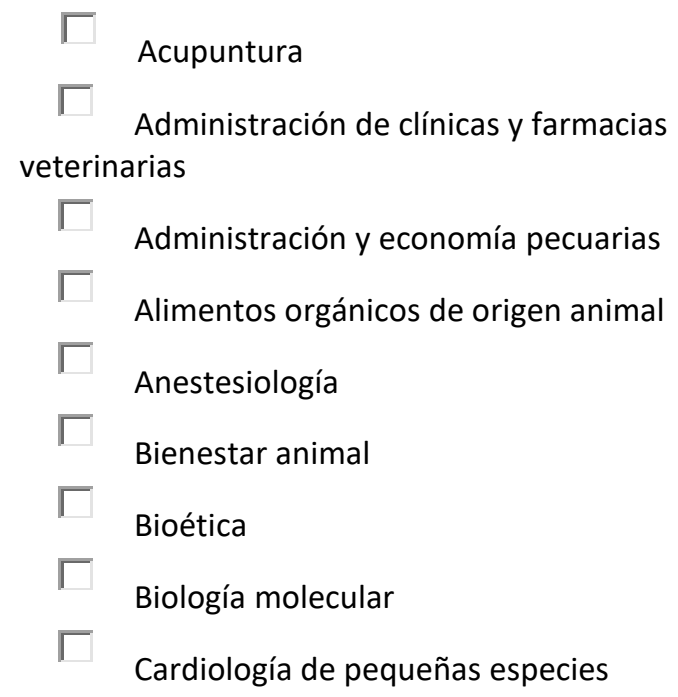

Acupuntura

Administración de clínicas y farmacias terinarias

Administración y economía pecuarias

Alimentos orgánicos de origen animal

Anestesiología

Bienestar animal

Bioética

— Cardiología de pequeñas especies
Ciencias Médicas Básicas

Cirugía de grandes especies

Cirugía de mascotas no tradicionales

Cirugía de pequeñas especies

Dermatología de pequeñas especies

Desarrollo rural

Economía y administración

Educación veterinaria y didáctica

Enfermedades emergentes y re-emergente 


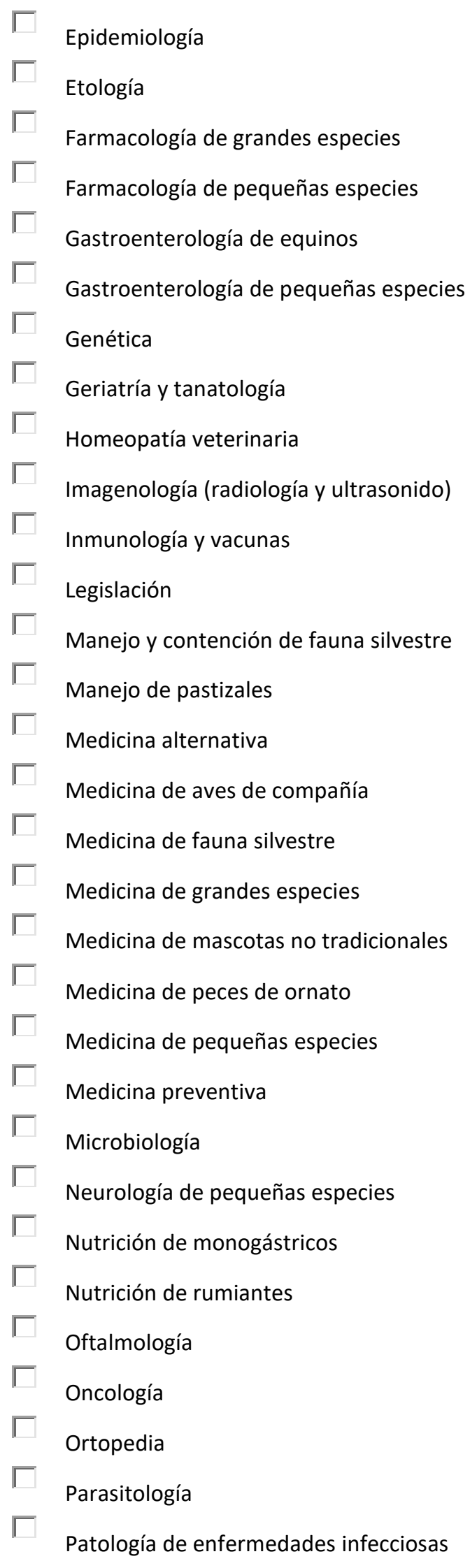

Patologías no infecciosas

Prevención de enfermedades

Producción bovina en el altiplano

Producción bovina en el trópico

- Producción caprina

Producción ovina

Producción piscícola

- Reproducción de bovinos

Reproducción de equinos

Reproducción de porcinos

Reproducción de pequeñas especies

Salud pública

Técnicas diagnósticas

Tecnologías de la información (cómputo)

Toxicología clínica

Urgencias médicas y terapia intensiva

Virología

Zoonosis

Zootecnia canina y felina

Otra... Especifique: 
6.-¿¿ué buscadores emplea para realizar sus búsquedas de información en internet?
$\Gamma \quad$ Excite
$\Gamma$ Altavista
Г Google
Г MSN
Г Yahoo
Г Google scholar
Г Otro... Especifique:

7.-Escriba uno o varios ejemplos que Usted emplea para realizar sus búsquedas de información en internet.

Ejemplo: Enfermedades toxico infecciosas de las aves [enter]

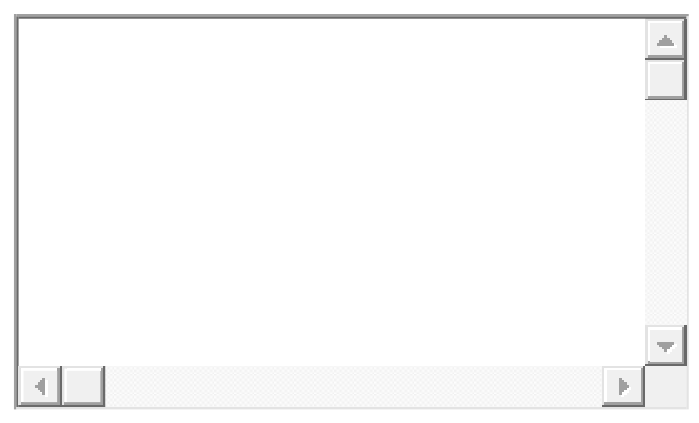

8.- De los resultados que le muestra el buscador, seleccione el motivo por el cuál decide activar (accesar)

$\Gamma$

Su breve descripción es apropiada a lo que busca

$\Gamma$ Porque aparece en los primeros resultados

$\Gamma \quad$ Porque conoce el sitio

$\Gamma$ Porque el sitio es de índole académico

$\Gamma \quad$ Porque el sitio proviene de un editor conocido

$\Gamma \quad$ Otro motivo... Especifique:

9.- De la información que le presenta el buscador, la que le resulta útil es porque
Г El sitio se actualiza constantemente
Г Puedo obtener el texto completo
ГEl sitio mantiene comunicación con sus lectores
$\lceil\quad$ Publican artículos de investigadores reconocidos 
10.- De la información que le presenta el buscador, la que NO CUBRE SU OBJETIVO es porque

Г La información del sitio no es vigente

ГCobran por tener acceso al texto completo

$\Gamma$ Tiene publicidad comercial

$\lceil\quad$ La información que presenta no está aprobada por comité editorial

$\Gamma \quad$ El sitio es muy confuso al desplegar su información

Г El sitio está plagado de ventanas emergentes o tiene pornografía

$\Gamma \quad$ El sitio es inaccesible

Г Otra causa... Especifique:

11.- ¿En promedio a cuántos resultados que aparecen en su buscador entra?
Máximo 3
C De 3 a 5
C De 5 a 10
C. Más de 10

12.- Seleccione qué tipo de información busca:

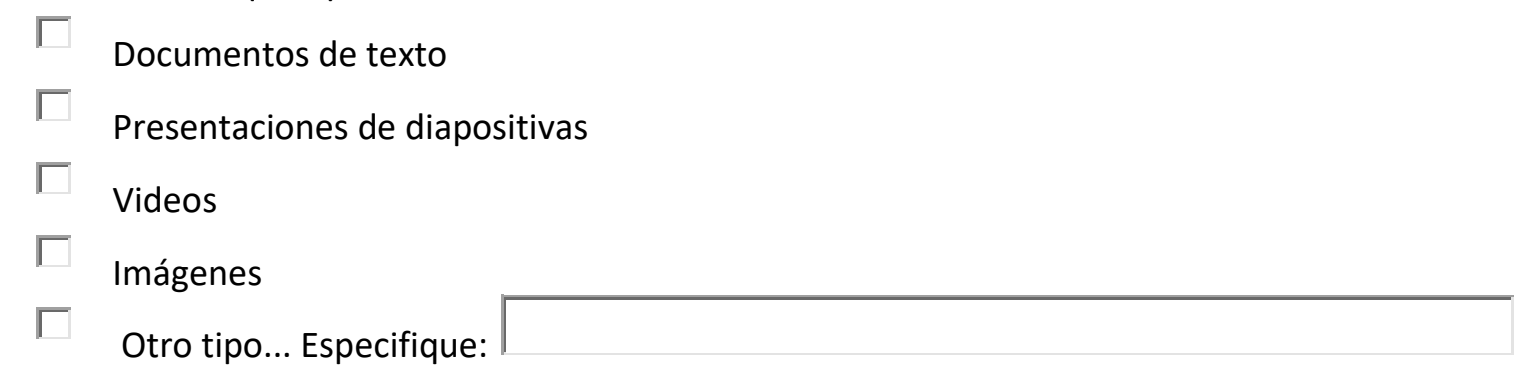

